\title{
Seed Halo-Priming Improves Seedling Vigor, Grain Yield, and Water Use Efficiency of Maize under Varying Irrigation Regimes
}

\author{
AbdAllah M. El-Sanatawy ${ }^{1}$, Salwa M.A.I. Ash-Shormillesy ${ }^{1}$, Naglaa Qabil ${ }^{1}$, Mohamed F. Awad ${ }^{2}$ (D) \\ and Elsayed Mansour $1, *$ (D) \\ 1 Department of Crop Science, Faculty of Agriculture, Zagazig University, Zagazig 44519, Egypt; \\ elsanatawyabdallah2@gmail.com (A.M.E.-S.); dr.salwaalymani@gmail.com (S.M.A.I.A.-S.); \\ naglaaqabil82@yahoo.com (N.Q.) \\ 2 Department of Biology, College of Science, Taif University, P.O. Box 11099, Taif 21944, Saudi Arabia; \\ m.fadl@tu.edu.sa \\ * Correspondence: sayed_mansour_84@yahoo.es
}

check for updates

Citation: El-Sanatawy, A.M.; Ash-Shormillesy, S.M.A.I.; Qabil, N.; Awad, M.F.; Mansour, E. Seed Halo-Priming Improves Seedling Vigor, Grain Yield, and Water Use Efficiency of Maize under Varying Irrigation Regimes. Water 2021, 13, 2115. https://doi.org/10.3390/ w13152115

Received: 5 July 2021

Accepted: 29 July 2021

Published: 31 July 2021

Publisher's Note: MDPI stays neutral with regard to jurisdictional claims in published maps and institutional affiliations.

Copyright: (c) 2021 by the authors. Licensee MDPI, Basel, Switzerland. This article is an open access article distributed under the terms and conditions of the Creative Commons Attribution (CC BY) license (https:// creativecommons.org/licenses/by/ $4.0 /)$.

\begin{abstract}
Water-deficit stress poses tremendous constraints to sustainable agriculture, particularly under abrupt climate change. Hence, it is crucial to find eco-friendly approaches to ameliorate drought tolerance, especially for sensitive crops such as maize. This study aimed at assessing the impact of seed halo-priming on seedling vigor, grain yield, and water use efficiency of maize under various irrigation regimes. Laboratory trials evaluated the influence of seed halo-priming using two concentrations of sodium chloride solution, 4000 and $8000 \mathrm{ppm} \mathrm{NaCl}$, versus unprimed seeds on seed germination and seedling vigor parameters. Field trials investigated the impact of halo-priming treatments on maize yield and water use efficiency (WUE) under four irrigation regimes comprising excessive (120\% of estimated crop evapotranspiration, ETc), normal (100\% ETc), and deficit (80 and $60 \%$ ETc) irrigation regimes. Over-irrigation by $20 \%$ did not produce significantly more grain yield but considerably reduced WUE. Deficit irrigation (80 and $60 \% \mathrm{ETc}$ ) gradually reduced grain yield and its attributes. Halo-priming treatments, particularly $4000 \mathrm{ppm} \mathrm{NaCl}$, improved uniformity and germination speed, increased germination percentage and germination index, and produced more vigorous seedlings with heavier dry weight compared with unprimed seeds. Under field conditions, the plants originated from halo-primed seeds, especially with $4000 \mathrm{ppm} \mathrm{NaCl}$, had higher grain yield and WUE compared with unprimed seeds under deficit irrigation regimes. The long-lasting stress memory induced by seed halo-priming, particularly with $4000 \mathrm{ppm} \mathrm{NaCl}$, promoted maize seedling establishment, grain yield, and WUE and consequently mitigated the devastating impacts of drought stress.
\end{abstract}

Keywords: halo-priming; sodium chloride; germination; water deficit; maize yield; water use efficiency

\section{Introduction}

Climate change poses tremendous constraints to sustainable crop production, particularly in arid environments [1]. Increasing temperature, wind speed, and solar radiation are projected due to abrupt climatic change [2]. These weather components are the main contributors to plant evapotranspiration and consequently will influence crop water requirements [3]. The Mediterranean region is considerably impacted by climatic variability and further adverse effects are expected [4]. Water shortage and frequent drought events immensely impede production of field crops, particularly in dry regions $[5,6]$. Maize (Zea mays L.) is one of the essential cereal crops worldwide in terms of its utilization and production [1,7]. Its global cultivated area is nearly 200 million hectares with a global production of about 1150 million tonnes [8]. Globally, maize is a major source of energy, feed, and industrial products, hence, it is constantly in increasing demand. Nevertheless, it is a crop sensitive to water deficit $[9,10]$ as both growth and production decline steeply 
under drought stress [11-14]. Water scarcity decreases photosynthetic pigments, transpiration rate, and photosynthetic efficiency, which destructively reflect on grain yield [15-18]. For that reason, it is crucial to find proper eco-friendly approaches to promote drought tolerance of maize, especially in arid environments under recent climate changes $[19,20]$. Recently, several studies have assessed different approaches to mitigate the destructive impacts of drought stress, focusing on seed priming, exogenous application of growth hormones, osmoprotectants, plant mineral nutrients, and nanoparticles [21-24].

Seed priming is an efficacious and easy pre-sowing treatment to strengthen plant defense against abiotic stresses [25-28]. It has beneficial impacts such as quickening germination, stimulating seedling growth, and elevating water use and nutrient uptake, subsequently stimulating plant growth [27]. There are different approaches to seed priming; halo-priming is one of these approaches that relies on soaking seeds in inorganic salt solution, i.e., $\mathrm{NaCl}, \mathrm{CaCl}_{2}, \mathrm{KNO}_{3}$, etc. [29-31]. The inorganic salt lowers water potential of seeds, which is similar to drought stress impacts [32]. Halo-priming triggers a physiological response of the seeds that acts on plant stress memory to make plants respond quickly and aggressively to imminent abiotic stress [28]. Plant stress memory is retained from seed halo-priming and exposure to osmotic stress $[25,33]$. Consequently, mild pretreatment stress can promote tolerance to upcoming other stresses [33]. Therefore, seed halo-priming is significantly beneficial to enhance plant tolerance to adverse environmental conditions and increase grain yield [32,34-37].

Based on the previous studies, the present work hypothesized that the application of seed halo-priming could remarkably enhance maize growth and productivity. Several studies have been performed on seed priming, but more knowledge is still needed about the response of maize to seed halo-priming in arid environments under different irrigation regimes. Thus, the present study aimed at (i) determining the impact of seed halo-priming on maize seed germination and seedling vigor measurements, (ii) investigating the influence of over-irrigation and deficit irrigation regimes on maize yield and WUE under arid conditions, and (iii) assessing the impact of seed halo-priming treatments on maize growth, productivity, and WUE under well-watered and water deficit irrigation conditions.

\section{Materials and Methods}

\subsection{Laboratory Experiment}

A set of 600 seeds (hybrid Giza-178) were purified with $0.1 \% \mathrm{HgCl}_{2}$ for $90 \mathrm{~s}$ and rinsed with distilled water. The seeds were split into three sets; the first one was soaked in $4000 \mathrm{ppm} \mathrm{NaCl}$ solution for $12 \mathrm{~h}$ (giving an osmotic potential of $-0.31 \mathrm{MPa}$ ), the second set was soaked in $8000 \mathrm{ppm} \mathrm{NaCl}$ solution for $12 \mathrm{~h}$ (giving an osmotic potential of $-0.62 \mathrm{MPa}$ ), and the third set was utilized as a control without any treatment (unprimed). The two treatments of seed halo-priming were performed separately at $20^{\circ} \mathrm{C}$ in the dark and the treated seeds were re-dried to their original weight using forced air at room temperature. Two days later after reaching the original weight, germination testing was conducted.

Four replicates of 40 seeds for each treatment were germinated at $25 \pm 1{ }^{\circ} \mathrm{C}$ in a dark growth chamber with $45 \%$ relative humidity in plastic germination plates with moist blotting. Seeds were determined germinated when their radical and coleoptile lengths reached $2 \mathrm{~mm}$. Germination count was performed every day and finished when no more germination was detected (after 10 days). The following germination and seedling vigor parameters were assessed: germination percentage (GP), seedling root length (RL), seedling shoot length (SL), seedling dry weight (SDW), seedling fresh weight (SFW), and seedling vigor index (SVI). Moreover, germination index (GI) was estimated following Abdul-Baki and Anderson [38], mean germination time (MGT) was determined according to Ellis and Roberts [39]; germination coefficient of velocity (GCV) was estimated following Maguire [40]. 


\subsection{Field Trial}

\subsubsection{Description of Experimental Site}

A two-year field experiment was performed on maize (Giza-178) at Abu-Hammad, Sharkia, Egypt $\left(30^{\circ} 32^{\prime} \mathrm{N}, 31^{\circ} 36^{\prime} \mathrm{E}\right)$, during successive summer seasons of 2018 and 2019. The experimental site is characterized as arid and no precipitation occurs during the summer season (Table 1). The experimental field soil was sandy clay in texture; its analysis is listed in Table 2. The prior crop was faba bean in both growing seasons. The plots were fertilized at rates of $32 \mathrm{~kg} \mathrm{P} \mathrm{ha}^{-1}, 94 \mathrm{~kg} \mathrm{~K} \mathrm{ha}^{-1}$, and $285 \mathrm{~kg} \mathrm{~N}$ ha $^{-1}$. Sowing took place on the first of May in both seasons according to the recommended period of maize growing in the study region. The other recommended agronomic practices in the study region encompassing pest, disease, and weed control were applied.

Table 1. Minimum ( $\mathrm{min})$ and maximum (max) temperatures, total precipitation (Prec), relative humidity (RH), and cumulative growing degree days (GDD) in 2018 and 2019 seasons as well as 22-year averages (1998-2019).

\begin{tabular}{cccccc}
\hline Month & Min $\left({ }^{\circ} \mathbf{C}\right)$ & Max $\left({ }^{\circ} \mathbf{C}\right)$ & Prec (mm) & RH (\%) & GDD $\left({ }^{\circ} \mathbf{C}\right)$ \\
\hline May & \multicolumn{5}{c}{ First season (2018) } \\
June & 19.9 & 32.2 & 0 & 43 & 497.6 \\
July & 22.1 & 34.2 & 0 & 45 & 544.5 \\
August & 24.2 & 34.7 & 0 & 56 & 602.9 \\
\hline & 24.8 & 35.3 & 0 & 56 & 521.3 \\
May & 20.8 & 34.3 & Second season (2019) \\
June & 23.3 & 35.3 & 0 & 42 & 544.1 \\
July & 24.8 & 35.9 & 0 & 49 & 579.0 \\
August & 25.4 & 35.6 & 0 & 54 & 630.9 \\
\hline & & \multicolumn{5}{c}{ 22-yr average } \\
May & 19.0 & 32.4 & 0 & 45 & \\
June & 21.4 & 34.4 & 0 & 47 & \\
July & 23.3 & 35.0 & 0 & 57 & \\
August & 20.5 & 31.9 & 0 & 61 & \\
\hline
\end{tabular}

Table 2. Soil properties of the experimental site (over two seasons 2018 and 2019).

\begin{tabular}{|c|c|c|c|c|c|c|}
\hline $\begin{array}{l}\text { Soil } \\
\text { Depth } \\
\text { (cm) }\end{array}$ & $\begin{array}{c}\text { Soil Bulk } \\
\text { Density } \\
\left(\mathrm{g} \mathrm{cm}^{-3}\right)\end{array}$ & $\begin{array}{c}\text { Field Capacity } \\
(\%)\end{array}$ & $\begin{array}{l}\text { Wilting } \\
\text { Point (\%) }\end{array}$ & $\begin{array}{c}\text { Available } \\
\text { Moisture } \\
\text { (\%) }\end{array}$ & $\mathrm{pH}$ & $\begin{array}{c}\text { Organic } \\
\text { Matter (\%) }\end{array}$ \\
\hline $0-30$ & 1.45 & 12.73 & 6.36 & 6.72 & 7.93 & 0.44 \\
\hline $30-60$ & 1.47 & 12.42 & 6.21 & 6.10 & 7.91 & 0.40 \\
\hline \multirow[t]{2}{*}{$60-90$} & 1.49 & 11.87 & 5.94 & 6.03 & 7.91 & 0.32 \\
\hline & $\begin{array}{c}\mathrm{EC} \\
\left(\mathrm{dS} \mathrm{m^{-1 }}\right)\end{array}$ & $\begin{array}{c}\text { Nitrogen } \\
\left(\mathrm{mg} \mathrm{kg}^{-1} \text { soil) }\right.\end{array}$ & Sand (\%) & Silt (\%) & Clay (\%) & Texture \\
\hline $0-30$ & 1.60 & 19.12 & 47.52 & 14.12 & 38.36 & Sandy clay \\
\hline $30-60$ & 1.56 & 16.91 & 47.71 & 14.05 & 38.24 & Sandy clay \\
\hline $60-90$ & 1.54 & 15.37 & 48.08 & 13.99 & 37.93 & Sandy clay \\
\hline
\end{tabular}

\subsubsection{Experimental Design and Studied Treatments}

Split-plot design was applied with three replicates. Main plots were allocated to irrigation regimes and the sub-plots were designated for seed halo-priming treatments (Figure 1). Four irrigation regimes were assessed; 120, 100, 80, and $60 \%$ of maize evapotranspiration (ETc). In addition, three seed priming treatments were applied, i.e., unprimed seeds, $4000 \mathrm{ppm}$, and $8000 \mathrm{ppm} \mathrm{NaCl}$ using the same procedures performed for the laboratory experiment. Each experimental plot area was $23.4 \mathrm{~m}^{2}$, which included 6 rows, $0.65 \mathrm{~m}$ apart and $6 \mathrm{~m}$ long, and the seeds were sown in hills with a distance of $0.25 \mathrm{~m}$. Irrigation 
was scheduled based on crop evapotranspiration (ETc) replacement following the crop coefficient approach according to Allen et al. [41]. Weather variables data were collected from a weather station sited at the experimental location. The amount of full irrigation $\left(100 \%\right.$ ETc) was 800.9 and $814.8 \mathrm{~mm} \mathrm{ha}^{-1}$ during first and second seasons, in the same order. The irrigation amount was decreased by 40 and $20 \%$ for irrigation levels of 60 and $80 \%$ ETc and increased by $20 \%$ for an irrigation level of $120 \%$ ETc. The irrigation treatments were applied after fifteen days from planting in both growing seasons to ensure complete field emergence. The drip irrigation system was applied to provide the experimental goals. Irrigation water amount was determined individually for each irrigation level employing a flow meter. Irrigation water was added in 12 events distributed throughout the growing season. Irrigation was stopped at about 20 days prior to harvesting in mid-August.

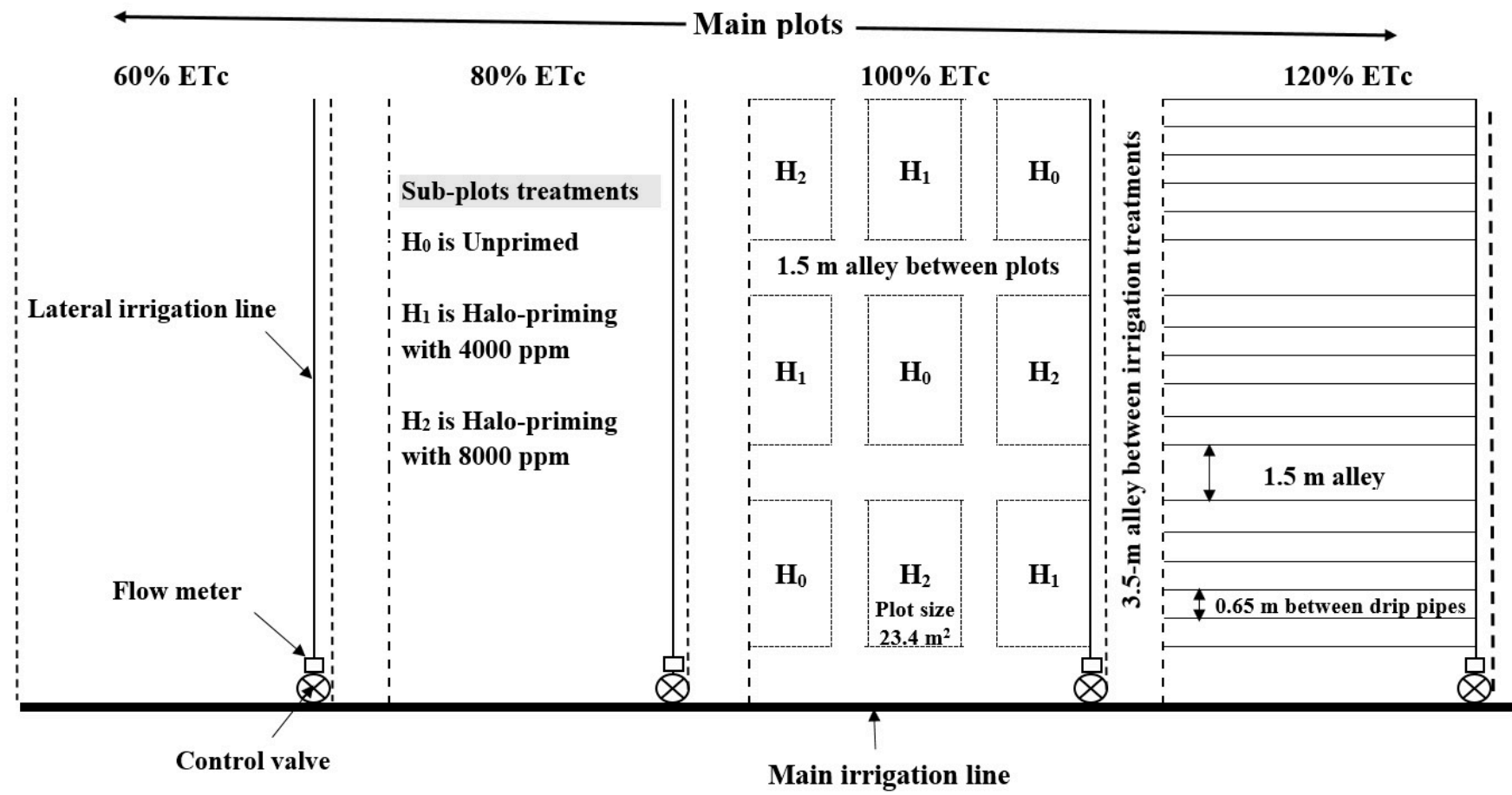

Figure 1. The experiment layout displaying four irrigation regimes in main plots and seed halo-priming treatments in subplots.

\subsubsection{Field Measurements}

Relative water content (RWC) was evaluated during the period of grain filling (90 DAS as outlined by Barrs and Weatherley [42]. At harvesting, ten plants were randomly collected from each plot to measure cob height $(\mathrm{cm})$, plant height $(\mathrm{cm})$, cob length $(\mathrm{cm})$, number of grains row ${ }^{-1}$, number of rows $\mathrm{cob}^{-1}$, grain weight $\mathrm{cob}^{-1}, 100$-grain weight (g), and shelling percentage. All maize plants of the central two rows were collected from each plot to estimate grain yield $\left(\mathrm{kg} \mathrm{m}^{-2}\right)$ then converted to $\mathrm{kg} \mathrm{ha}^{-1}$. Grain yield was estimated from shelled cobs (was modified to $15.5 \%$ moisture content). Harvest index (\%) was calculated as the ratio of grain yield divided by above-ground biological yield. Water use efficiency (WUE, $\mathrm{kg} \mathrm{ha}^{-1} \mathrm{~mm}^{-1}$ ) was estimated as grain yield divided by $\mathrm{ET}_{\mathrm{C}}$ according to Greaves and Wang [43].

\subsection{Statistical Analysis}

Data of laboratory and field experiments were analyzed using completely randomized design and split-plot analysis, respectively, using the package Agricolae [44] in R statistical software version 3.6.1. Differences among treatments were separated by the least significant difference (LSD) at $p \leq 0.05$. Regression model of quadratic-plateau was applied to explore the relationship between irrigation water regimes and grain yield for three priming 
treatments using GraphPad Prism. The breakpoint in the response curve representing the minimum irrigation amount to produce maximum grain yield for the priming treatments was identified by the program. The principal component analysis was performed using the R statistical software package Factoextra [45].

\section{Results}

\subsection{Laboratory Experiment}

The obtained results manifested that seed halo-priming with $4000 \mathrm{ppm} \mathrm{NaCl}$ significantly promoted the germination process through increasing germination percentage and germination index. It exhibited $93.3 \%$ of germination percentage and a germination index of 18.1 compared with unprimed seeds that had $80.0 \%$ and 8.6 representing $16.7 \%$ and $109 \%$ increases in these parameters, respectively (Table 3). Moreover, the same treatment significantly produced more vigorous seedlings with heavier fresh and dry weight (increased by 11.0 and $26.6 \%$ ) as well as a higher seedling vigor index (increased by $47.7 \%$ in comparison with unprimed seeds). Furthermore, halo-priming treatment with $4000 \mathrm{ppm}$ $\mathrm{NaCl}$ substantially hastened the germination process through reducing mean germination time by $11.3 \%$ compared with unprimed seeds. Otherwise, halo-priming seeds with $8000 \mathrm{ppm} \mathrm{NaCl}$ had a considerably lesser effect on the germination process and seedling vigor (Table 3). This reflects that seed halo-priming with $4000 \mathrm{ppm} \mathrm{NaCl}$ has a stimulating impact on seed germination and maize seedling establishment.

Table 3. Impact of seed halo-priming treatments with 4000 and $8000 \mathrm{ppm}$ versus unprimed seeds on maize seed germination and seedling vigor parameters.

\begin{tabular}{|c|c|c|c|c|c|c|c|}
\hline \multirow{2}{*}{$\begin{array}{c}\text { Parameter } \\
\text { Germination percentage }(\%)\end{array}$} & \multicolumn{2}{|c|}{ Unprimed } & \multicolumn{2}{|c|}{ Halo-Priming with 4000 ppm } & \multicolumn{2}{|c|}{ Halo-Priming with 8000 ppm } & \multirow{2}{*}{$\begin{array}{c}p \text {-Value } \\
0.001\end{array}$} \\
\hline & 80.00 & $\mathrm{~b}$ & 93.33 & $\mathrm{a}$ & 74.67 & c & \\
\hline Mean germination time (day) & 7.24 & $\mathrm{a}$ & 6.42 & $\mathrm{~b}$ & 6.48 & $\mathrm{~b}$ & $<0.001$ \\
\hline $\begin{array}{l}\text { Germination coefficient of } \\
\text { velocity }(\text { seed day }\end{array}$ & 13.79 & $\mathrm{~b}$ & 15.56 & a & 15.41 & a & $<0.001$ \\
\hline Germination index (seed day ${ }^{-1}$ ) & 8.62 & $\mathrm{~b}$ & 18.06 & $\mathrm{a}$ & 13.88 & c & $<0.001$ \\
\hline Root length (cm) & 14.28 & & 14.79 & & 14.80 & & 0.511 \\
\hline Shoot length $(\mathrm{cm})$ & 5.02 & $\mathrm{~b}$ & 5.87 & $\mathrm{a}$ & 5.48 & $\mathrm{a}$ & 0.048 \\
\hline Seedling fresh weight $(\mathrm{mg})$ & 660.25 & $\mathrm{~b}$ & 732.68 & $\mathrm{a}$ & 684.82 & $\mathrm{~b}$ & 0.018 \\
\hline Seedling dry weight (mg) & 216.07 & c & 273.62 & $\mathrm{a}$ & 250.50 & $\mathrm{~b}$ & 0.001 \\
\hline Seedling vigor index (unitless) & 17.28 & $\mathrm{~b}$ & 25.53 & $\mathrm{a}$ & 18.70 & $\mathrm{~b}$ & $<0.001$ \\
\hline
\end{tabular}

Means followed by different letters in each row differ significantly by LSD $(p<0.05)$.

\subsection{Field Trial}

Excessive irrigation by raising the irrigation regime from $100 \%$ to $120 \%$ ETc failed to achieve a significant increase in RWC, cob height, plant height, cob length, number of grains row ${ }^{-1}$, number of rows $\mathrm{cob}^{-1}, 100$-grain weight, grain weight $\mathrm{cob}^{-1}$, shelling percentage, grain yield, and harvest index, but significantly decreased WUE (Tables 4 and 5). In contrast, subjecting plants to water scarcity by decreasing the irrigation level from $100 \%$ to 80 or $60 \%$ ETc was accompanied by a significant reduction in all aforementioned traits, except WUE, which increased. Moreover, the negative impacts of severe drought $(60 \% \mathrm{ETc})$ were more pronounced than those of moderate drought stress (80\% ETc). Evidently, severe drought stress reduced RWC by $27.8 \%$, plant height by $26.0 \%$, cob height by $16.2 \%$, cob length by $28.5 \%$, number of rows $\mathrm{cob}^{-1}$ by $17.2 \%$, number of grains row ${ }^{-1}$ by $32.0 \%$, grain weight $\mathrm{cob}^{-1}$ by $36.4 \%$, 100-grain weight by $21.2 \%$, shelling percentage by $7.3 \%$, grain yield by $63.4 \%$, and harvest index by $20.4 \%$ compared with well-watered treatments ( $100 \%$ ETc). 
Table 4. Effect of irrigation regimes and seed halo-priming treatments on relative water content (RWC), cob height, plant height, cob length, number of grains row ${ }^{-1}$, and number of rows $\mathrm{cob}^{-1}$ during two growing seasons of 2018 and 2019.

\begin{tabular}{|c|c|c|c|c|c|c|c|c|c|c|c|c|c|}
\hline \multirow{2}{*}{\multicolumn{2}{|c|}{ Factor }} & \multicolumn{4}{|c|}{ RWC (\%) } & \multicolumn{4}{|c|}{ Cob Height (cm) } & \multicolumn{4}{|c|}{ Plant Height (cm) } \\
\hline & & \multicolumn{2}{|c|}{2018} & \multicolumn{2}{|c|}{2019} & \multicolumn{2}{|c|}{2018} & \multicolumn{2}{|c|}{2019} & \multicolumn{2}{|c|}{2018} & \multicolumn{2}{|c|}{2019} \\
\hline \multicolumn{14}{|c|}{ Irrigation regimes (I) } \\
\hline $120 \%$ ETc & & 77.24 & A & $76.31^{\circ}$ & A & 140.95 & A & 142.16 & A & 300.51 & A & 297.80 & A \\
\hline $100 \% \mathrm{ETc}$ & & 75.89 & A & 75.34 & A & 137.11 & A & 138.52 & A & 296.55 & A & 294.05 & A \\
\hline $80 \%$ ETc & & 61.92 & B & 64.49 & B & 126.64 & $\mathrm{~B}$ & 122.20 & B & 258.28 & B & 261.65 & B \\
\hline $60 \%$ ETc & & 54.52 & C & 54.67 & C & 116.72 & C & 114.31 & C & 217.42 & C & 219.46 & C \\
\hline \multicolumn{14}{|c|}{ Seed halo-priming $(\mathrm{H})$} \\
\hline Unprimed & & 64.80 & $\mathrm{~b}$ & 65.18 & $\mathrm{~b}$ & 134.99 & & 136.22 & & 264.62 & $\mathrm{~b}$ & 265.19 & $\mathrm{~b}$ \\
\hline Halo-priming with 40 & $\mathrm{pm}$ & 68.53 & a & 68.75 & a & 133.35 & & 132.68 & & 268.86 & $\mathrm{ab}$ & 268.42 & $\mathrm{ab}$ \\
\hline Halo-priming with 80 & $\mathrm{pm}$ & 68.86 & $\mathrm{a}$ & 69.18 & a & 131.44 & & 131.81 & & 270.09 & a & 270.11 & a \\
\hline ANOVA & df & \multicolumn{12}{|c|}{$p$-Value } \\
\hline Irrigation regime (I) & 3 & $<0.001$ & & $<0.001$ & & $<0.001$ & & $<0.001$ & & $<0.001$ & & $<0.001$ & \\
\hline Seed halo-priming $(\mathrm{H})$ & 2 & $<0.001$ & & 0.002 & & 0.615 & & $<0.324$ & & 0.048 & & 0.047 & \\
\hline $\mathrm{I} \times \mathrm{H}$ & 6 & $<0.001$ & & 0.031 & & 0.038 & & $<0.001$ & & 0.040 & & 0.035 & \\
\hline \multirow{2}{*}{\multicolumn{2}{|c|}{ Studied Factors }} & \multicolumn{4}{|c|}{ Cob Length (cm) } & \multicolumn{4}{|c|}{ Number of Grains Row ${ }^{-1}$} & \multicolumn{4}{|c|}{ Number of Rows $\mathrm{Cob}^{-1}$} \\
\hline & & \multicolumn{2}{|c|}{2018} & \multicolumn{2}{|c|}{2019} & \multicolumn{2}{|c|}{2018} & \multicolumn{2}{|c|}{2019} & \multicolumn{2}{|c|}{2018} & \multicolumn{2}{|c|}{2019} \\
\hline \multicolumn{14}{|c|}{ Irrigation regimes (I) } \\
\hline $120 \% \mathrm{ETc}$ & & 20.36 & A & $21.12^{\circ}$ & A & 36.38 & A & 38.37 & A & 13.52 & A & 13.44 & A \\
\hline $100 \%$ ETc & & 19.90 & A & 20.79 & A & 36.22 & A & 38.36 & A & 13.13 & A & 13.27 & A \\
\hline $80 \%$ ETc & & 17.86 & B & 17.59 & B & 28.62 & B & 32.91 & B & 12.54 & B & 11.63 & B \\
\hline $60 \%$ ETc & & 14.98 & C & 14.10 & C & 24.69 & C & 26.00 & C & 11.08 & C & 10.77 & C \\
\hline \multicolumn{14}{|c|}{ Seed halo-priming (H) } \\
\hline Unprimed & & 17.67 & $\mathrm{~b}$ & 18.05 & $\mathrm{~b}$ & 30.03 & $\mathrm{~b}$ & 32.50 & $\mathrm{~b}$ & 12.46 & & 12.09 & \\
\hline Halo-priming with 40 & $\mathrm{pm}$ & 18.51 & a & 18.46 & a & 32.43 & $\mathrm{a}$ & 34.80 & a & 12.61 & & 12.34 & \\
\hline Halo-priming with 80 & $\mathrm{pm}$ & 18.65 & a & 18.69 & a & 31.96 & a & 34.44 & a & 12.64 & & 12.41 & \\
\hline ANOVA & df & \multicolumn{12}{|c|}{$p$-Value } \\
\hline Irrigation regime (I) & 3 & $<0.001$ & & $<0.001$ & & $<0.001$ & & $<0.001$ & & $<0.001$ & & $<0.001$ & \\
\hline Seed halo-priming $(\mathrm{H})$ & 2 & 0.007 & & 0.005 & & $<0.001$ & & $<0.001$ & & 0.818 & & 0.370 & \\
\hline $\mathrm{I} \times \mathrm{H}$ & 6 & 0.039 & & 0.021 & & $<0.001$ & & 0.017 & & 0.029 & & 0.047 & \\
\hline
\end{tabular}

Means of irrigation levels followed by distinct uppercase letters and means of halo-priming treatments followed by distinct lowercase letters differ significantly by LSD $(p<0.05)$.

Table 5. Effect of irrigation regimes and seed halo-priming treatments on grain weight cob $^{-1}$, 100-grain weight, shelling percentage, grain yield ha ${ }^{-1}$, harvest index (HI), and water use efficiency (WUE) during two seasons of 2018 and 2019.

\begin{tabular}{|c|c|c|c|c|c|c|c|c|c|c|c|c|c|}
\hline \multirow{2}{*}{\multicolumn{2}{|c|}{ Factor }} & \multicolumn{4}{|c|}{ Grain Weight $\mathrm{Cob}^{-1}$} & \multicolumn{4}{|c|}{ 100-Grain Weight (g) } & \multicolumn{4}{|c|}{ Shelling Percentage } \\
\hline & & \multicolumn{2}{|c|}{2018} & \multicolumn{2}{|c|}{2019} & \multicolumn{2}{|c|}{2018} & \multicolumn{2}{|c|}{2019} & \multicolumn{2}{|c|}{2018} & \multicolumn{2}{|c|}{2019} \\
\hline \multicolumn{14}{|c|}{ Irrigation regimes (I) } \\
\hline $120 \%$ ETc & & 137.14 & A & 128.48 & A & 27.85 & A & 27.55 & A & 75.76 & A & 74.18 & A \\
\hline $100 \% \mathrm{ETc}$ & & 135.42 & A & 126.05 & A & 27.35 & A & 27.17 & A & 74.65 & A & 73.82 & A \\
\hline $80 \%$ ETc & & 105.56 & B & 101.09 & B & 23.54 & B & 23.97 & B & 72.07 & $\mathrm{~B}$ & 71.69 & B \\
\hline $60 \%$ ETc & & 86.60 & $\mathrm{C}$ & 79.50 & C & 21.30 & C & 21.68 & C & 68.64 & $\mathrm{~B}$ & 69.05 & B \\
\hline \multicolumn{14}{|c|}{ Seed halo-priming $(\mathrm{H})$} \\
\hline Unprimed & & 110.47 & c & 102.80 & c & 23.59 & c & 23.59 & c & 72.26 & $\mathrm{~b}$ & 71.27 & $\mathrm{~b}$ \\
\hline Halo-priming with 40 & pm & 121.89 & a & 113.85 & $\mathrm{a}$ & 26.29 & $\mathrm{a}$ & 26.29 & $\mathrm{a}$ & 74.08 & a & 73.78 & a \\
\hline Halo-priming with 80 & $\mathrm{pm}$ & 116.18 & $\mathrm{~b}$ & 109.70 & $\mathrm{~b}$ & 25.4 & $\mathrm{~b}$ & 25.4 & $\mathrm{~b}$ & 73.51 & a & 73.01 & a \\
\hline ANOVA & $\mathrm{df}$ & \multicolumn{12}{|c|}{$p$-Value } \\
\hline Irrigation regime (I) & 3 & $<0.001$ & & $<0.001$ & & $<0.001$ & & $<0.001$ & & 0.001 & & 0.003 & \\
\hline Seed halo-priming $(\mathrm{H})$ & 2 & $<0.001$ & & $<0.001$ & & $<0.001$ & & $<0.001$ & & $<0.001$ & & $<0.001$ & \\
\hline $\mathrm{I} \times \mathrm{H}$ & 6 & $<0.001$ & & $<0.001$ & & $<0.001$ & & $<0.001$ & & 0.008 & & 0.029 & \\
\hline
\end{tabular}


Table 5. Cont.

\begin{tabular}{|c|c|c|c|c|c|c|c|c|c|c|c|c|c|}
\hline \multirow{2}{*}{\multicolumn{2}{|c|}{ Studied Factors }} & \multicolumn{4}{|c|}{ Grain Yield (kg ha $\left.{ }^{-1}\right)$} & \multicolumn{4}{|c|}{ Harvest Index (\%) } & \multicolumn{4}{|c|}{ WUE (kg ha $\left.{ }^{-1} \mathrm{~mm}^{-1}\right)$} \\
\hline & & \multicolumn{2}{|c|}{2018} & \multicolumn{2}{|c|}{2019} & \multicolumn{2}{|c|}{2018} & \multicolumn{2}{|c|}{2019} & \multicolumn{2}{|c|}{2018} & \multicolumn{2}{|c|}{2019} \\
\hline \multicolumn{14}{|c|}{ Irrigation regimes (I) } \\
\hline $120 \%$ ETc & & 7305 & A & 7348 & A & 37.23 & A & 36.62 & $\mathrm{~A}$ & 9.49 & C & 9.37 & C \\
\hline $100 \%$ ETc & & 7271 & A & 7288 & A & 37.66 & A & 37.60 & A & 11.34 & B & 11.15 & B \\
\hline $80 \%$ ETc & & 6145 & B & 6185 & B & 32.47 & B & 32.16 & B & 11.98 & A & 11.83 & A \\
\hline $60 \%$ ETc & & 4723 & C & 4532 & C & 29.32 & C & 30.61 & $\mathrm{C}$ & 12.28 & A & 11.55 & A \\
\hline \multicolumn{14}{|c|}{ Seed halo-priming $(\mathrm{H})$} \\
\hline Unprimed & & 6141 & c & 6131 & c & 32.35 & $\mathrm{~b}$ & 32.87 & $\mathrm{~b}$ & 10.78 & c & 10.53 & c \\
\hline Halo-priming with 40 & pm & 6560 & a & 6538 & $\mathrm{a}$ & 35.50 & a & 35.23 & $\mathrm{a}$ & 11.71 & a & 11.41 & a \\
\hline Halo-priming with 80 & pm & 6381 & $\mathrm{~b}$ & 6346 & $\mathrm{~b}$ & 34.66 & a & 34.65 & $\mathrm{a}$ & 11.34 & $\mathrm{~b}$ & 10.99 & $\mathrm{~b}$ \\
\hline ANOVA & df & \multicolumn{12}{|c|}{$p$-Value } \\
\hline Irrigation regime (I) & 3 & $<0.001$ & & $<0.001$ & & $<0.001$ & & $<0.001$ & & $<0.001$ & & $<0.001$ & \\
\hline Seed halo-priming $(\mathrm{H})$ & 2 & $<0.001$ & & $<0.001$ & & $<0.001$ & & $<0.001$ & & $<0.001$ & & $<0.001$ & \\
\hline $\mathrm{I} \times \mathrm{H}$ & 6 & 0.005 & & 0.007 & & 0.002 & & $<0.001$ & & $<0.001$ & & $<0.001$ & \\
\hline
\end{tabular}

Means of irrigation regimes followed by distinct uppercase letters and means of halo-priming treatments followed by distinct lowercase letters differ significantly by LSD $(p<0.05)$.

Halo-primed seeds enhanced RWC, cob length, number of grains row ${ }^{-1}, 100$-grain weight, grain weight $\mathrm{cob}^{-1}$, shelling percentage, grain yield, harvest index, and WUE values, while no significant alterations were observed in cob height, plant height, and number of rows $\mathrm{cob}^{-1}$ due to halo-priming treatments. The stimulating impacts on maize seeds primed with $4000 \mathrm{ppm} \mathrm{NaCl}$ exceeded those of priming with $8000 \mathrm{ppm} \mathrm{NaCl}$. The halo-priming with $4000 \mathrm{ppm}$ boosted number of grains row ${ }^{-1}$ by $7.5 \%$, grain weight $\mathrm{cob}^{-1}$ by $10.5 \%, 100$-grain weight by $11.4 \%$, grain yield by $6.7 \%$, harvest index by $8.4 \%$, and WUE by $8.5 \%$ compared with unprimed treatment.

Significant interaction impacts between irrigation levels and seed halo-priming treatments were observed for all studied traits (Tables 4 and 5) and are presented in Figures 2 and 3. Regardless of seed halo-priming treatments, no significant effects were observed in grain yield and its related attributes with a $20 \%$ increase of irrigation above ETc. Moreover, the impact of halo-primed treatments was not significant under well-watered conditions (120 and $100 \% \mathrm{ETc}$ ), while seed halo-priming treatments exhibited statistically significant impacts under moderate and severe drought stress $(80 \%$ and $60 \%$ ETc). The plants originating from halo-primed seeds showed lower reductions in yield-related traits and increased WUE under water deficit conditions (Figure 3). Clearly, the impact of halo-priming with $4000 \mathrm{ppm}$ $\mathrm{NaCl}$ surpassed that of $8000 \mathrm{ppm}$ on 100-grain weight, grain weight $\mathrm{cob}^{-1}$, grain yield, and WUE under drought stress conditions. The halo-priming with $4000 \mathrm{ppm}$ elevated number of grains row ${ }^{-1}$ by $22.4 \%$, grain weight $\mathrm{cob}^{-1}$ by $26.5 \%$, 100 -grain weight by $26.3 \%$, grain yield by $21.3 \%$, harvest index by $24.2 \%$, and WUE by $21.7 \%$ in comparison with unprimed treatment under severe drought conditions. Accordingly, it can be concluded that the positive role of seed halo-priming, particularly with $4000 \mathrm{ppm} \mathrm{NaCl}$, was more powerful under water stress conditions. 

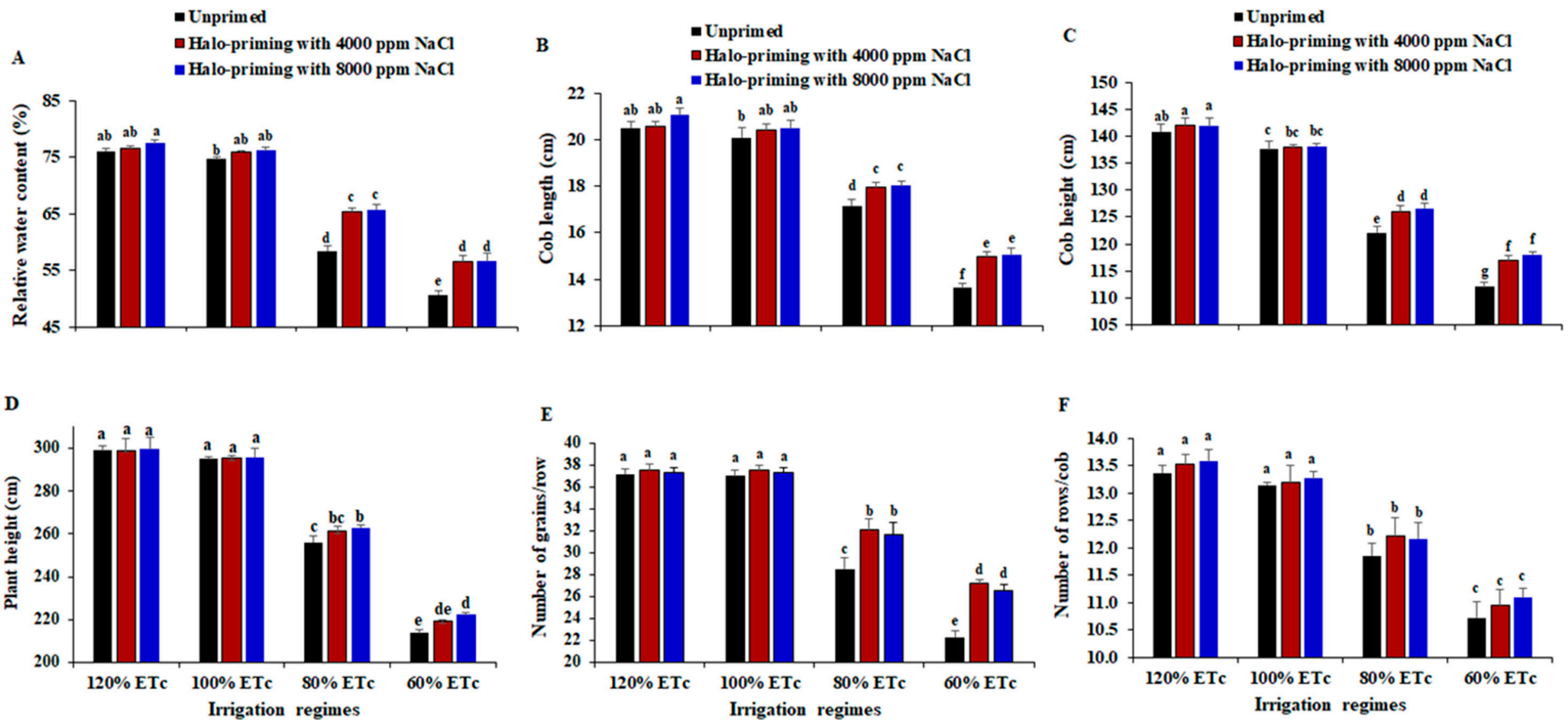

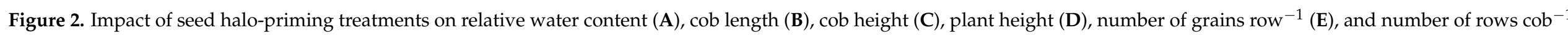

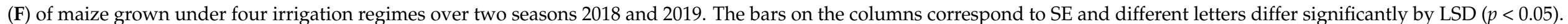



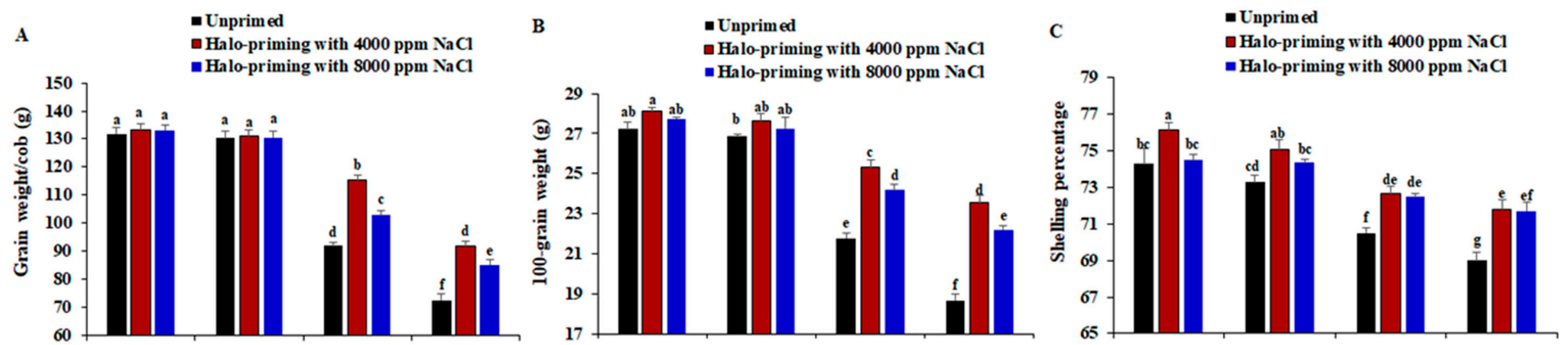

D
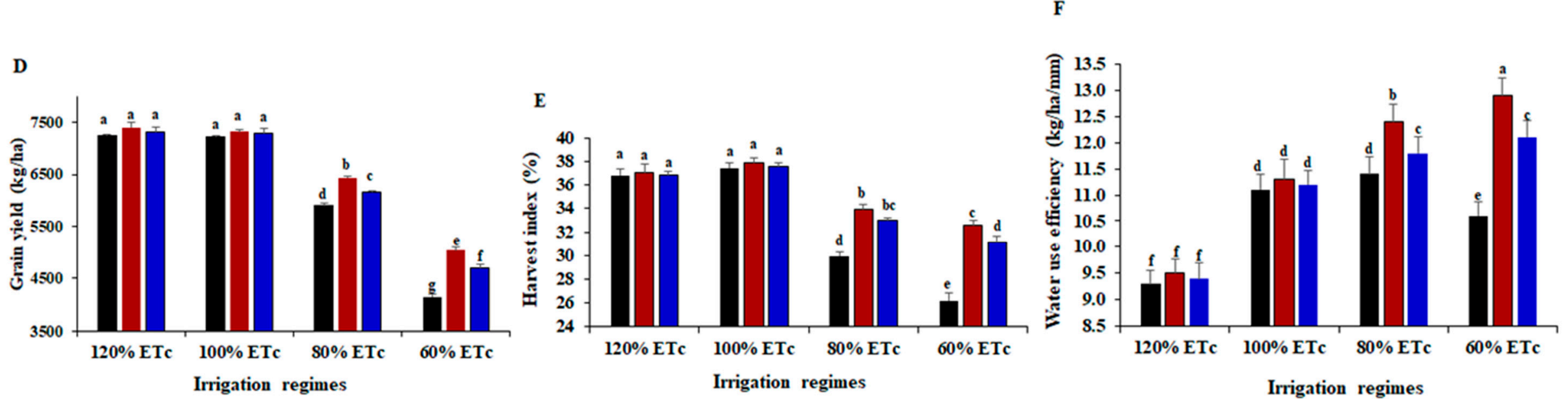

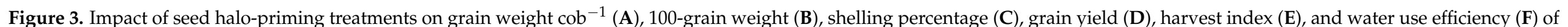
maize under four irrigation regimes over two seasons 2018 and 2019. The bars on the columns correspond to SE and different letters differ significantly by LSD ( $p<0.05)$. 


\subsubsection{Response of Grain Yield to Irrigation Regimes}

The relationship between irrigation regimes and grain yield as influenced by seed halopriming is described in Figure 4. The three priming treatments showed a quadratic convex diminishing response. The breakpoint in the response curve was detected at $757 \mathrm{~mm}$. This point represents the minimum irrigation amount to produce maximum grain yield for the priming treatments, which were 6799,7055 , and $6919 \mathrm{~kg} \mathrm{ha}^{-1}$ for seeds unprimed, halo-primed with $4000 \mathrm{ppm} \mathrm{NaCl}$ and $8000 \mathrm{ppm} \mathrm{NaCl}$, respectively. Accordingly, the plants originating from seed halo-primed with $4000 \mathrm{ppm}$ could produce a higher grain yield using the same water amount compared to those halo-primed with $8000 \mathrm{ppm}$ and unprimed treatments. Moreover, the predicted economic grain yield for unprimed seeds (6799 $\mathrm{kg} \mathrm{ha}^{-1}$ ) could be produced using a lower irrigation amount $(696.2 \mathrm{~mm})$ using seeds halo-primed with $4000 \mathrm{ppm} \mathrm{NaCl}$. This implies that seeds halo-primed with $4000 \mathrm{ppm}$ $\mathrm{NaCl}$ produce superior grain yield, especially under drought stress as presented in Figure 4.

-..- Unprimed

-.- Halo-priming with $4000 \mathrm{ppm}$ Nacl $Y=-503.6+16.28 \mathrm{X}+0.008317 \mathrm{X}^{2}$

- Halo-priming with $8000 \mathrm{ppm}$ Nacl $Y=-1393+17.79 \mathrm{X}+0.009007 \mathrm{X}^{2}$

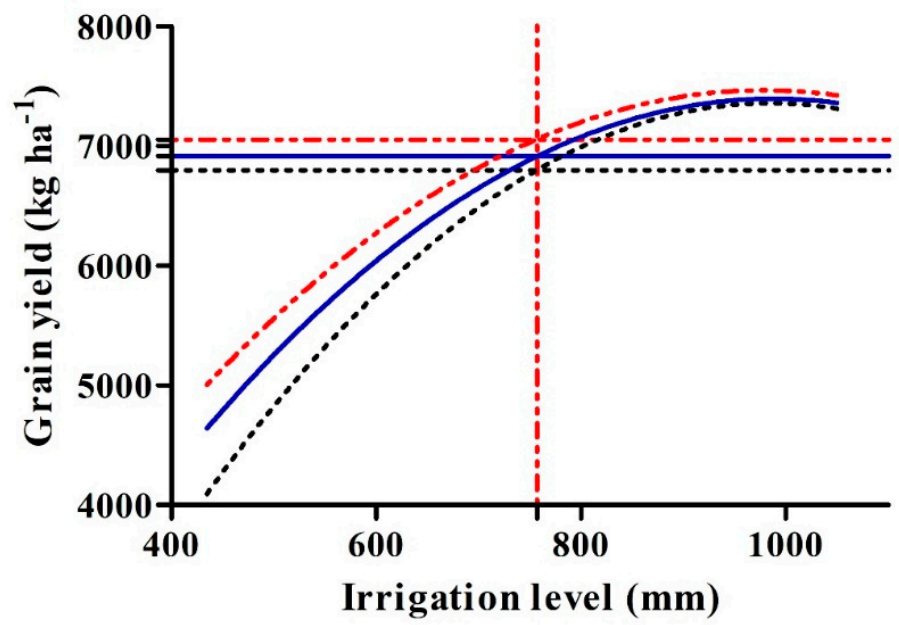

Figure 4. Response of grain yield to irrigation regimes and determining minimum irrigation amount to produce economic grain yield for the three priming treatments.

\subsubsection{Interrelationship among Studied Traits and Treatments}

Principal component analysis (PCA) was used to assess the association among the investigated traits and treatments as presented in Figure 5. The first two PCAs accounted for $97.79 \%$ of the variability. The PCA1 explained $80.8 \%$ of the variation and was related to increasing the irrigation regimes from $60 \%$ to $120 \%$ ETc (Figure 5). The increase from $100 \%$ to $120 \%$ ETc had a small effect as depicted by the small distance of plots from these treatments along PCA1, while the distance in the multidimensional spaces of $60 \%$ and $80 \%$ ETc irrigation regimes were much more spread out, implying dissimilarity. The PCA1 divided the irrigation levels into two groups; the excessive and full irrigation regimes were situated on the positive side but those of moderate and severe drought stress were located on the negative side (Figure 5). The PCA2 explained $16.8 \%$ of the variation and seems to correspond with seed halo-priming treatments, from bottom to top as unprimed, $8000 \mathrm{ppm}$ and $4000 \mathrm{ppm}$. Seed treatments were more dissimilar with plots under severe drought conditions (60\% ETc) compared with moderated drought ( $80 \% \mathrm{ETc})$ or well-watered irrigation regimes (120 and 100\% ETc). Grain yield and its attributes were associated with well-watered irrigation regimes (120 and 100\% ETc) in the PCA1, whereas WUE was associated with seeds halo-primed with $4000 \mathrm{ppm} \mathrm{NaCl}$ under severe $(60 \% \mathrm{ETc})$ 
and moderate ( $80 \%$ ETc) drought stress regimes. Regardless of irrigation regimes, seed treatments were ordered in PCA2 from unprimed to $4000 \mathrm{ppm}$ treatment following an increase of WUE. The adjacent vectors of traits reflect a strong positive association while vectors with larger angles prove a weak association, and opposite vectors $\left(\right.$ at $180^{\circ}$ ) reveal a negative relationship. A strong positive association was observed among grain yield and all its attributes, while there was a negative association with WUE. As expected from the results previously presented, grain yield and related traits were positively correlated and opposite to those of WUE. Moreover, no significant difference was detected between $100 \%$ and $120 \%$ ETc and as well as the positive impact of halo-priming with $4000 \mathrm{ppm}$ on WUE under drought stress. Hence, the PCA biplot reinforced the aforementioned presented results.

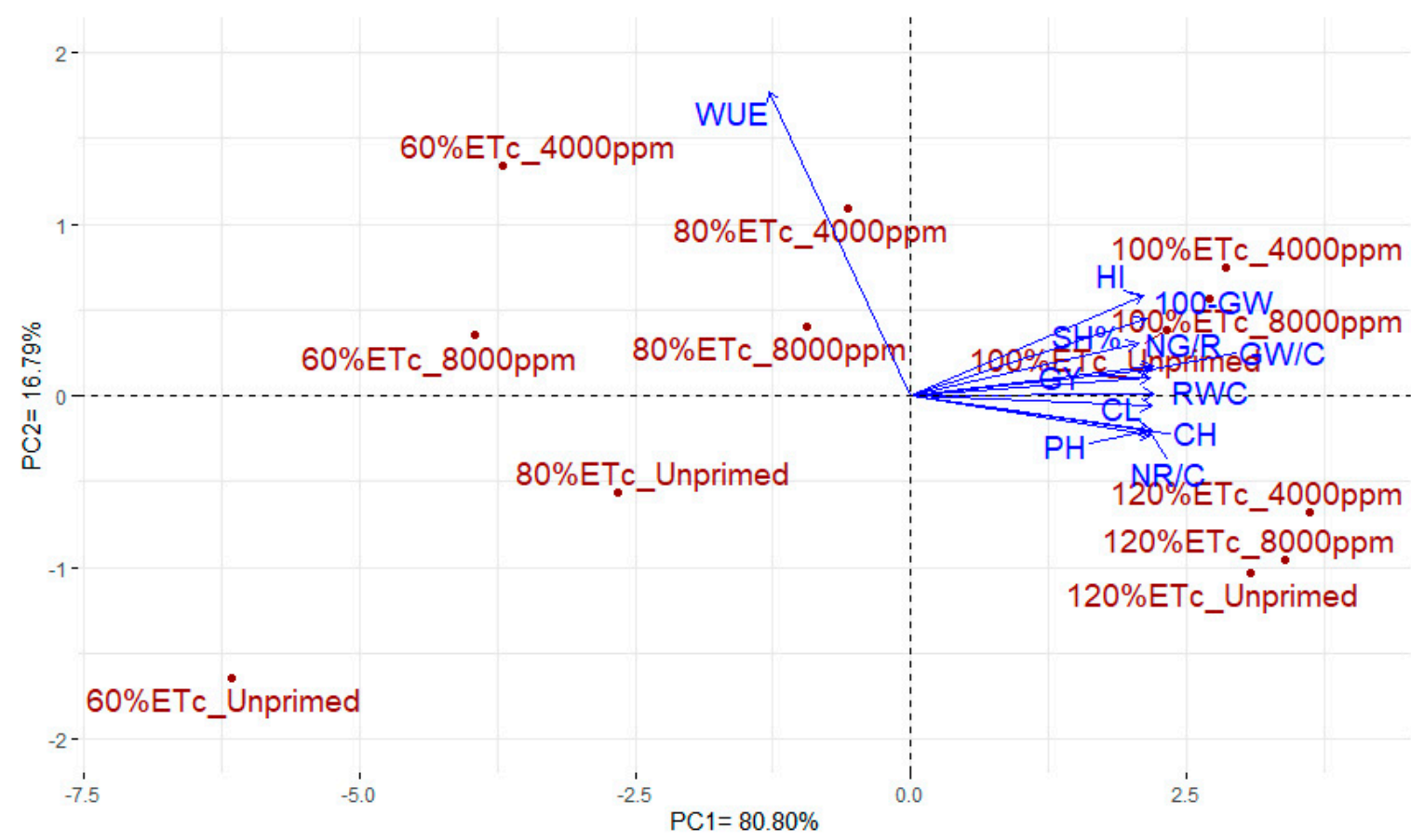

Figure 5. PCA biplot for the evaluated traits of maize under four irrigation regimes and two halo-priming treatments over two seasons 2018 and 2019. RWC: relative water content, CH: cob height, PH: plant height, CL: cob length, NG/R: number of grains row ${ }^{-1}$, NRC: number of rows $\mathrm{cob}^{-1}$, GW/C: grain weight $\mathrm{cob}^{-1}$, 100-GW: 100-grain weight, $\mathrm{SH} \%$ : shelling percentage, GY: grain yield, WUE: water use efficiency, and HI: harvest index.

\section{Discussion}

Maize water requirements are expected to vary with climate change [46,47]. Consequently, it is necessary to assess irrigation requirements regularly to achieve high yields without losing water by over-irrigation or exposing plants to devastating impacts of drought stress. In the current study, four irrigation levels were evaluated $(120,100,80$, and $60 \%$ ETc) to study the effects of excessive and deficit irrigation (severe and moderate) conditions on maize grain yield and WUE. Certain researchers deduced that excessive irrigation by $120 \%$ and $125 \%$ of irrigation water requirements increased maize grain yield $[9,48,49]$. On the contrary, others proved that excessive irrigation failed to produce a substantial increase in grain yield in comparison with full irrigation level [12,50]. In our case, the results manifested that excessive irrigation up to $120 \%$ ETc had no significant influence on all the studied agronomic traits, but it significantly decreased WUE. Enhancing WUE is essential, particularly in arid environments, to cope with the limitation of irrigation water [51]. Accordingly, increasing irrigation amounts by more than $100 \%$ ETc is not advised in arid regions due to the decline of water supplies owing to climatic changes [10]. 
Water deficit substantially reduces photosynthetic efficiency, stomatal conductance, transpiration rate, membrane stability index, water relations, and nutrient uptake which negatively reflects on maize growth and productivity $[15,19,52,53]$. The obtained results exhibited that deficit irrigation levels (60\% and $80 \%$ ETc) gradually reduced maize yield and its attributes (Tables 3 and 4). Deficit irrigation caused a decline in RWC (Table 3), which describes the water status of the plant. The reduction in RWC in plant cells resulted in stunted plants and impeded plant growth. Drought stress seriously hindered maize development and growth by reducing cell size and cell division in meristematic tissues [54-57]. Moreover, water deficit causes a reduction in pollen production during the vegetative stage [58], silking rate during flowering stage [59], ovule fertilization during reproductive stage [60,61], accelerating senescence during maturity stage, and reducing grain filling rate and duration [62-64], reducing accumulation of photosynthetic products. Accordingly, yield traits of cob length, number grains row ${ }^{-1}$, number of rows $\mathrm{cob}^{-1}, 100$ grain weight, and grain weight $\mathrm{cob}^{-1}$ gradually declined under deficit irrigation regimes. This was further displayed by the biplot of principal components since the agronomic traits associated with $100 \%$ ETc were on opposite sites to $80 \%$ and $60 \%$ ETc irrigation regimes (Figure 5). Similar adverse impacts of water deficit were demonstrated by Zhang et al. [64]; Bharathi et al. [65]; Siyami et al. [66]; Jiang et al. [67]; Mansour et al. [68]; Sohail et al. [69]; Nawaz et al. [70]; and Attia et al. [71].

Maize is a crop sensitive to water deficit and its production is tremendously influenced by drought stress. Hence, it is crucial to identify proper approaches to ameliorate drought tolerance, particularly under arid environments. Halo-priming is an affordable approach to promote drought tolerance [30,72]. The obtained results revealed that halo-priming treatments hastened the germination development and reduced mean germination period in comparison with unprimed seed, showing superiority of halo-priming seed with $4000 \mathrm{ppm}$ $\mathrm{NaCl}$. Moreover, seed halo-priming with $4000 \mathrm{ppm} \mathrm{NaCl}$ boosted germination percentage, germination index, and seedling vigor index in comparison with unprimed seeds. On the other hand, germination percentage and germination index were lower using $8000 \mathrm{ppm}$ $\mathrm{NaCl}$ solution, which may be attributed to the toxic effect of high-level accumulation of $\mathrm{Na}^{+}$and $\mathrm{Cl}^{-}$ions in maize seeds. In this context, Bakht et al. [73] disclosed that maize seeds halo-primed with $3480 \mathrm{ppm}$ exhibited significant positive impacts on days to emergence, germination rate, shoot fresh and dry weight, shoot contents of $\mathrm{Na}^{+}, \mathrm{K}^{+}$, proline, and abscisic acid, leaf area, plant height, and yield traits; but increasing salinity level in halo-priming treatment up to $5120 \mathrm{ppm}$ displayed negative impacts on plant development and growth.

Germination and seedling establishment are crucial stages that greatly impact maize growth and productivity. Fast and uniform emergence, as well as vigorous seedlings, are prerequisites for strong growth, particularly under environmental stresses [74]. Strong established seedlings have a high ability to compete for resources and interact better with biotic stresses and usually have a higher yield $[75,76]$. Similar results were pointed out by Jisha and Puthur [37] Patade et al. [32] and Gholami et al. [77] who disclosed that halo-priming is an efficacious pre-germination procedure for synchronized and faster seed germination. Besides, Damalas et al. [76] and Eskandari and Kazemi [78] depicted that halo-priming is a useful approach for promoting seedling vigor and establishment. In this context, Shrestha et al. [79] manifested that halo-priming stimulates metabolic activities in the early phases of germination. Subsequently, the accomplishment of pre-germination metabolic activities may be the probable reason for faster and more vigorous emergence of the primed seeds compared to the unprimed ones. Moreover, Gao et al. [80] proved that halo-priming improves seedling emergence and seed germination by enhancing the expression of aquaporins.

Exposure to abiotic stress (as halo-priming) induces stress memory which prepares the plant for faster germination and to better tolerate the upcoming stress events [81-83]. Maize plants originated from halo-primed seeds retained a long-lasting stress memory that promoted the stress scavenging mechanism under water deficit conditions. Drought 
tolerance induced by halo-priming regulated physiological and biochemical processes and enabled maize plants to sustain their productivity under water deficit conditions. Likewise, Patade et al. [32]; Langeroodi and Noora [84]; Iqbal et al. [34]; Khaing et al. [35] proved the vital role of seed halo-priming in ameliorating plant tolerance of adverse environmental conditions and increasing grain yield. Additionally, Bajehbaj [36] elucidated that $\mathrm{NaCl}$ priming elevates $\mathrm{K}$ and $\mathrm{Ca}$ accumulation in plant cells and induced osmoregulation by elevating the accumulation of proline. Proline accumulation induces water retention and mitigates the devastating impacts of drought stress [84,85].

The obtained results displayed that the influence of halo-primed treatments was not significant under well-watered conditions but was more evident under drought stress. The plants originating from halo-primed seeds exhibited higher RWC than unprimed seeds under deficit irrigation ( $60 \%$ and $80 \%$ ETc) with superiority of $4000 \mathrm{ppm} \mathrm{NaCl}$. RWC exposes the water balance in plant cells and is considered a good indicator of plant water status [57]. Moreover, seeds primed with $4000 \mathrm{ppm} \mathrm{NaCl}$ significantly produced substantially heavier 100-grain weight, grain weight $\mathrm{cob}^{-1}$, grain yield ha ${ }^{-1}$, and higher WUE under water deficit conditions compared with $8000 \mathrm{ppm}$ and unprimed treatments. Markedly, seed halo-priming with $4000 \mathrm{ppm} \mathrm{NaCl}$ increased grain yield by $21.3 \%$, harvest index by $24.2 \%$ and WUE by $21.7 \%$ compared with unprimed seeds under severe drought stress conditions. Moreover, the response of grain yield to irrigation regimes revealed that halo-priming with $4000 \mathrm{ppm} \mathrm{NaCl}$ could produce higher grain yield utilizing less irrigation water under water shortage in comparison with unprimed treatment (Figure 4). Besides, WUE was associated with seeds halo-primed with $4000 \mathrm{ppm} \mathrm{NaCl}$ under severe $(60 \% \mathrm{ETc})$ and moderate ( $80 \%$ ETc) drought stress conditions (Figure 5). Thereby, the obtained results denoted that halo-priming with $4000 \mathrm{ppm} \mathrm{NaCl}$ has a valuable role in promoting plant water status and alleviating destructive impacts of drought stress.

\section{Conclusions}

Excessive irrigation using $120 \%$ ETc did not produce significantly higher grain yield but significantly decreased WUE. Deficit irrigation regimes (60\% and $80 \%$ ETc) gradually decreased grain yield and its attributes. It is noteworthy that the efficacy of seed halo-priming was more pronounced under drought stress. The results implied that the plant stress memory induced by seed halo-priming, particularly with $4000 \mathrm{ppm} \mathrm{NaCl}$, ameliorated maize seedling establishment, grain yield, and WUE under drought stress. Halo-priming with $4000 \mathrm{ppm} \mathrm{NaCl}$ could be exploited to produce higher grain yield utilizing less irrigation water, especially under drought stress.

Author Contributions: CConceptualization, A.M.E.-S., S.M.A.I.A.-S., N.Q. and E.M.; methodology, A.M.E.-S., S.M.A.I.A.-S., N.Q. and E.M.; software, A.M.E.-S., S.M.A.I.A.-S., N.Q., M.F.A. and E.M.; validation, A.M.E.-S., S.M.A.I.A.-S., N.Q., M.F.A. and E.M.; formal analysis, A.M.E.-S., S.M.A.I.A.-S., N.Q. and E.M.; in-vestigation, A.M.E.-S., S.M.A.I.A.-S., N.Q. and E.M.; writing-original draft preparation, A.M.E.-S., S.M.A.I.A.-S., N.Q., M.F.A. and E.M.; writing-review and editing, A.M.E.-S., S.M.A.I.A.-S., N.Q., M.F.A. and E.M. All authors have read and agreed to the published version of the manuscript.

Funding: This research received no external funding.

Institutional Review Board Statement: Not applicable.

Informed Consent Statement: Not applicable.

Data Availability Statement: The data presented in this study are available upon request from the corresponding author.

Acknowledgments: The authors wish to thank Zagazig University for the technical and financial support of this research. The authors extend their appreciation to the Taif University for funding this work through Taif University Researchers Supporting Project number (TURSP -2020/111), Taif University, Taif, Saudi Arabia.

Conflicts of Interest: The authors declare no conflict of interest. 


\section{References}

1. Liu, M.; Xu, X.; Jiang, Y.; Huang, Q.; Huo, Z.; Liu, L.; Huang, G. Responses of crop growth and water productivity to climate change and agricultural water-saving in arid region. Sci. Total Environ. 2020, 703, 134621. [CrossRef] [PubMed]

2. Lawin, A.E.; Niyongendako, M.; Manirakiza, C. Solar irradiance and temperature variability and projected trends analysis in Burundi. Climate 2019, 7, 83. [CrossRef]

3. Shahid, S. Impact of climate change on irrigation water demand of dry season Boro rice in northwest Bangladesh. Clim. Chang. 2011, 105, 433-453. [CrossRef]

4. Mansour, E.; Moustafa, E.S.; Qabil, N.; Abdelsalam, A.; Wafa, H.A.; El Kenawy, A.; Casas, A.M.; Igartua, E. Assessing different barley growth habits under Egyptian conditions for enhancing resilience to climate change. Field Crop. Res. 2018, $224,67-75$. [CrossRef]

5. Meza, I.; Siebert, S.; Döll, P.; Kusche, J.; Herbert, C.; Eyshi Rezaei, E.; Nouri, H.; Gerdener, H.; Popat, E.; Frischen, J. Global-scale drought risk assessment for agricultural systems. Nat. Hazards Earth Syst. Sci. 2020, 20, 695-712. [CrossRef]

6. Mansour, E.; Desoky, E.M.; Ali, M.M.A.; Abdul-Hamid, M.I.; Ullah, H.; Attia, A.; Datta, A. Identifying drought-tolerant genotypes of faba bean and their agro-physiological responses to different water regimes in an arid Mediterranean environment. Agric. Water Manag. 2021, 247, 106754. [CrossRef]

7. Tabak, M.; Lepiarczyk, A.; Filipek-Mazur, B.; Lisowska, A. Efficiency of nitrogen fertilization of winter wheat depending on sulfur fertilization. Agronomy 2020, 10, 1304. [CrossRef]

8. FAOSTAT. Food and Agriculture Organization of the United Nations. Statistical Database. 2021. Available online: http: / / www.fao.org/faostat/en/\#data (accessed on 26 June 2021).

9. Kuscu, H.; Karasu, A.; Mehmet, O.; Demir, A.O.; Turgut, I. Effect of irrigation amounts applied with drip irrigation on maize evapotranspiration, yield, water use efficiency, and net return in a suba" humid climate. Turkish J. Field Crop. 2013, $18,13-19$.

10. Jia, Q.; Sun, L.; Ali, S.; Liu, D.; Zhang, Y.; Ren, X.; Zhang, P.; Jia, Z. Deficit irrigation and planting patterns strategies to improve maize yield and water productivity at different plant densities in semi-arid regions. Sci. Rep. 2017, 7, 1-13. [CrossRef] [PubMed]

11. Prăvălie, R.; Patriche, C.V.; Sirodoev, I.; Bandoc, G.; Dumitraşcu, M.; Peptenatu, D. Water deficit and corn productivity during the post-socialist period. Case study: Southern Oltenia drylands, Romania. Arid. Land Res. Manag. 2016, 30, 239-257. [CrossRef]

12. Karasu, A.; Kușcu, H.; Mehmet, Ö.; Bayram, G. The effect of different irrigation water levels on grain yield, yield components and some quality parameters of silage Maize (Zea mays indentata Sturt.). Not. Bot. Horti. Agrobot. Cluj Napoca 2015, 43, 138-145. [CrossRef]

13. Ran, H.; Kang, S.; Li, F.; Du, T.; Ding, R.; Li, S.; Tong, L. Responses of water productivity to irrigation and N supply for hybrid maize seed production in an arid region of Northwest China. J. Arid Land 2017, 9, 504-514. [CrossRef]

14. Jha, P.K.; Ines, A.V.; Singh, M.P. A multiple and ensembling approach for calibration and evaluation of genetic coefficients of CERES-maize to simulate maize phenology and yield in Michigan. Environ. Model. Softw. 2021, 135, 104901. [CrossRef]

15. Hussain, H.A.; Men, S.; Hussain, S.; Chen, Y.; Ali, S.; Zhang, S.; Zhang, K.; Li, Y.; Xu, Q.; Liao, C. Interactive effects of drought and heat stresses on morpho-physiological attributes, yield, nutrient uptake and oxidative status in maize hybrids. Sci. Rep. 2019, 9, 1-12. [CrossRef]

16. Sharifi, P.; Mohammadkhani, N. Effects of drought stress on photosynthesis factors in wheat genotypes during anthesis. Cereal Res. Commun. 2016, 44, 229-239. [CrossRef]

17. Ostrowska, A.; Grzesiak, M.T.; Hura, T. Exogenous application of growth stimulators improves the condition of maize exposed to soil drought. Acta Physiol. Plant 2021, 43, 1-9. [CrossRef]

18. Desoky, E.-S.M.; Elrys, A.S.; Mansour, E.; Eid, R.S.; Selem, E.; Rady, M.M.; Ali, E.F.; Mersal, G.A.; Semida, W.M. Application of biostimulants promotes growth and productivity by fortifying the antioxidant machinery and suppressing oxidative stress in faba bean under various abiotic stresses. Sci. Hortic. 2021, 288, 110340. [CrossRef]

19. Desoky, E.-S.M.; Mansour, E.; Ali, M.; Yasin, M.A.; Abdul-Hamid, M.I.; Rady, M.M.; Ali, E.F. Exogenously used 24-epibrassinolide promotes drought tolerance in maize hybrids by improving plant and water productivity in an arid environment. Plants 2021, 10, 354. [CrossRef]

20. Vicente-Serrano, S.M.; Beguería, S.; Gimeno, L.; Eklundh, L.; Giuliani, G.; Weston, D.; El Kenawy, A.; López-Moreno, J.I.; Nieto, R.; Ayenew, T. Challenges for drought mitigation in Africa: The potential use of geospatial data and drought information systems. Appl. Geogr. 2012, 34, 471-486. [CrossRef]

21. Desoky, E.-S.M.; Mansour, E.; Yasin, M.A.; El Sobky, E.-S.E.; Rady, M.M. Improvement of drought tolerance in five different cultivars of Vicia faba with foliar application of ascorbic acid or silicon. Span. J. Agric. Res. 2020, 18, 16. [CrossRef]

22. El-Sanatawy, A.M.; El-Kholy, A.S.; Ali, M.; Awad, M.F.; Mansour, E. Maize seedling establishment, grain yield and crop water productivity response to seed priming and irrigation management in a Mediterranean arid environment. Agronomy 2021, 11, 756. [CrossRef]

23. Seleiman, M.F.; Al-Suhaibani, N.; Ali, N.; Akmal, M.; Alotaibi, M.; Refay, Y.; Dindaroglu, T.; Abdul-Wajid, H.H.; Battaglia, M.L. Drought stress impacts on plants and different approaches to alleviate its adverse effects. Plants 2021, 10, 259. [CrossRef] [PubMed]

24. Marthandan, V.; Geetha, R.; Kumutha, K.; Renganathan, V.G.; Karthikeyan, A.; Ramalingam, J. Seed priming: A feasible strategy to enhance drought tolerance in crop plants. Int. J. Mol. Sci. 2020, 21, 8258. [CrossRef] 
25. Qin, F.; Xu, H.-l.; Ci, D. Drought stimulation by hypocotyl exposure altered physiological responses to subsequent drought stress in peanut seedlings. Acta Physiol. Plant 2017, 39, 1-15. [CrossRef]

26. Hussain, S.; Hussain, S.; Khaliq, A.; Ali, S.; Khan, I. Physiological, Biochemical, and Molecular Aspects of Seed Priming. In Priming and Pretreatment of Seeds and Seedlings; Springer: Berlin/Heidelberg, Germany, 2019; pp. 43-62.

27. Rhaman, M.S.; Rauf, F.; Tania, S.S.; Khatun, M. Seed priming methods: Application in field crops and future perspectives. Asian J. Crop Sci. 2020, 5, 8-19. [CrossRef]

28. Jisha, K.; Vijayakumari, K.; Puthur, J.T. Seed priming for abiotic stress tolerance: An overview. Acta Physiol. Plant 2013, 35, 1381-1396. [CrossRef]

29. Jisha, K.; Puthur, J.T. Halopriming of seeds imparts tolerance to $\mathrm{NaCl}$ and PEG induced stress in Vigna radiata (L.) Wilczek varieties. Physiol. Mol. Biol. Plants. 2014, 20, 303-312. [CrossRef] [PubMed]

30. Afzal, I.; Rauf, S.; Basra, S.; Murtaza, G. Halopriming improves vigor, metabolism of reserves and ionic contents in wheat seedlings under salt stress. Plant Soil Environ. 2008, 54, 382-388. [CrossRef]

31. Kumari, N.; Rai, P.K.; Bara, B.M.; Singh, I. Effect of halo priming and hormonal priming on seed germination and seedling vigour in maize (Zea mays L.) seeds. J. Pharmacogn. Phytochem. 2017, 6, 27-30.

32. Patade, V.Y.; Bhargava, S.; Suprasanna, P. Halopriming imparts tolerance to salt and PEG induced drought stress in sugarcane. Agric. Ecosyst. Environ. 2009, 134, 24-28. [CrossRef]

33. Llorens, E.; González-Hernández, A.I.; Scalschi, L.; Fernández-Crespo, E.; Camañes, G.; Vicedo, B.; García-Agustín, P. Priming mediated stress and cross-stress tolerance in plants: Concepts and opportunities. In Priming-Mediated Stress and Cross-Stress Tolerance in Crop Plants; Elsevier: Amsterdam, The Netherlands, 2020; pp. 1-20.

34. Iqbal, H.; Yaning, C.; Waqas, M.; Ahmed, Z.; Raza, S.T.; Shareef, M. Improving heat stress tolerance in late planted spring maize by using different exogenous elicitors. Chil. J. Agric. Res. 2020, 80, 30-40. [CrossRef]

35. Khaing, M.; Ultra Jr, V.; Chul Lee, S. Seed priming influence on growth, yield, and grain biochemical composition of two wheat cultivars. J. Agric. Sci. Technol. 2020, 22, 875-888.

36. Bajehbaj, A.A. The effects of $\mathrm{NaCl}$ priming on salt tolerance in sunflower germination and seedling grown under salinity conditions. Afr. J. Biotechnol. 2010, 9, 1764-1770.

37. El-Sanatawy, A.M.; Zedan, A.T.M. Seed treatment for improving wheat productivity under deficit irrigation conditions in arid environment. Soil Environ. 2020, 39, 38-49. [CrossRef]

38. Abdul-Baki, A.A.; Anderson, J.D. Vigor determination in soybean seed by multiple criteria 1. Crop Sci. 1973, 13, 630-633. [CrossRef]

39. Ellis, R.; Roberts, E. The quantification of ageing and survival in orthodox seeds. Seed Sci. Technol. 1981, 9, 377-409.

40. Maguire, J.D. Speed of germination-Aid in selection and evaluation for seedling emergence and vigor 1. Crop Sci. 1962, 2, 176-177. [CrossRef]

41. Allen, R.G.; Pereira, L.S.; Raes, D.; Smith, M. Crop evapotranspiration-Guidelines for computing crop water requirements-FAO Irrigation and drainage paper 56. Fao Rome 1998, 300, D05109.

42. Barrs, H.; Weatherley, P. A re-examination of the relative turgidity technique for estimating water deficits in leaves. Aust. J. Biol. Sci. 1962, 15, 413-428. [CrossRef]

43. Greaves, G.E.; Wang, Y.-M. Effect of regulated deficit irrigation scheduling on water use of corn in southern Taiwan tropical environment. Agric. Water Manag. 2017, 188, 115-125. [CrossRef]

44. De Mendiburu, F. Agricolae: Statistical procedures for agricultural research. $R$ Packag. Version 2014, 1, 1-4.

45. Kassambara, A.; Mundt, F. Factoextra: Extract and visualize the results of multivariate data analyses. $R$ Packag. Version 2017, 1 , 337-354.

46. Cammarano, D.; Ronga, D.; Di Mola, I.; Mori, M.; Parisi, M. Impact of climate change on water and nitrogen use efficiencies of processing tomato cultivated in Italy. Agric. Water Manag. 2020, 241, 106336. [CrossRef]

47. Uçak, A.B. Identification of water usage efficiency for corn (Zea mays 1.) lines irrigated with drip irrigation under green house conditions as per plant water stress index evaluations. Turk. J. Agric. Res. 2017, 4, 1-9. [CrossRef]

48. Bozkurt, S.; Yazar, A.; Mansuroglu, G.S. Effects of different drip irrigation levels on yield and some agronomic characteristics of raised bed planted corn. Afr. J. Agric. Res. 2011, 6, 5291-5300.

49. Zou, H.; Fan, J.; Zhang, F.; Xiang, Y.; Wu, L.; Yan, S. Optimization of drip irrigation and fertilization regimes for high grain yield, crop water productivity and economic benefits of spring maize in Northwest China. Agric. Water Manag. 2020, $230,105986$. [CrossRef]

50. Irmak, S.; Djaman, K.; Rudnick, D.R. Effect of full and limited irrigation amount and frequency on subsurface drip-irrigated maize evapotranspiration, yield, water use efficiency and yield response factors. Irrig. Sci. 2016, 34, 271-286. [CrossRef]

51. El-Mageed, A.; Taia, A.; Belal, E.E.; Rady, M.O.; El-Mageed, A.; Shimaa, A.; Mansour, E.; Awad, M.F.; Semida, W.M. Acidified biochar as a soil amendment to drought stressed (Vicia faba L.) plants: Influences on growth and productivity, nutrient status, and water use efficiency. Agronomy 2021, 11, 1290. [CrossRef]

52. Shemi, R.; Wang, R.; Gheith, E.-S.M.; Hussain, H.A.; Hussain, S.; Irfan, M.; Cholidah, L.; Zhang, K.; Zhang, S.; Wang, L. Effects of salicylic acid, zinc and glycine betaine on morpho-physiological growth and yield of maize under drought stress. Sci. Rep. 2021, 11, 1-14. [CrossRef] 
53. Chávez-Arias, C.C.; Ligarreto-Moreno, G.A.; Ramírez-Godoy, A.; Restrepo-Díaz, H. Maize responses challenged by drought, elevated daytime temperature and arthropod herbivory stresses: A physiological, biochemical and molecular view. Front. Plant Sci. 2021, 12, 702841. [CrossRef]

54. Tsukaya, H. Does ploidy level directly control cell size? Counterevidence from Arabidopsis genetics. PLoS ONE 2013, 8, e83729. [CrossRef] [PubMed]

55. Efeoğlu, B.; Ekmekçi, Y.; Çiçek, N. Physiological responses of three maize cultivars to drought stress and recovery. S. Afr. J. Bot. 2009, 75, 34-42. [CrossRef]

56. Avramova, V.; AbdElgawad, H.; Zhang, Z.; Fotschki, B.; Casadevall, R.; Vergauwen, L.; Knapen, D.; Taleisnik, E.; Guisez, Y.; Asard, H. Drought induces distinct growth response, protection, and recovery mechanisms in the maize leaf growth zone. Plant Physiol. 2015, 169, 1382-1396. [CrossRef]

57. Badr, A.; Brueggemann, W. Comparative analysis of drought stress response of maize genotypes using chlorophyll fluorescence measurements and leaf relative water content. Photosynthetica 2020, 58, 638-645. [CrossRef]

58. Wang, J.; Tong, L.; Kang, S.; Li, F.; Zhang, X.; Ding, R.; Du, T.; Li, S. Flowering characteristics and yield of maize inbreds grown for hybrid seed production under deficit irrigation. Crop Sci. 2017, 57, 2238-2250. [CrossRef]

59. Hammad, H.M.; Ahmad, A.; Abbas, F.; Farhad, W.; Cordoba, B.C.; Hoogenboom, G. Water and nitrogen productivity of maize under semiarid environments. Crop Sci. 2015, 55, 877-888. [CrossRef]

60. NeSmith, D.; Ritchie, J. Effects of soil water-deficits during tassel emergence on development and yield component of maize (Zea mays). Field Crop. Res. 1992, 28, 251-256. [CrossRef]

61. Rafiee, M.; Kalhor, M. Economic water use efficiency of corn (Zea mays L.) hybrids as affected by irrigation regimes: A case study in West Iran. Arch. Agron. Soil Sci. 2016, 62, 781-789. [CrossRef]

62. Comas, L.H.; Trout, T.J.; DeJonge, K.C.; Zhang, H.; Gleason, S.M. Water productivity under strategic growth stage-based deficit irrigation in maize. Agric. Water Manag. 2019, 212, 433-440. [CrossRef]

63. Tan, F.Y.; Li, H.; Wang, J.L.; Wang, Z.W. Response of dry matter partitioning coefficient of summer maize to drought stress in North China. J. Appl. Ecol. 2019, 30, 217-223.

64. Zhang, H.; Han, M.; Comas, L.H.; DeJonge, K.C.; Gleason, S.M.; Trout, T.J.; Ma, L. Response of maize yield components to growth stage-based deficit irrigation. Agron. J. 2019, 111, 1-9. [CrossRef]

65. Bharathi, A.; Ragavan, T.; Geethalakshmi, V.; Rathinasamy, A.; Amutha, R. Influence of deficit irrigation schedules on nutrient uptake of maize hybrid under drip system. J. Pharmacogn. Phytochem. 2018, 7, 272-275.

66. Siyami, R.; Mirshekari, B.; Farahvash, F.; Rashidi, V.; Tarinejad, A. The effect of physical priming of seed on traits and yield of corn (Zea mays L.) under water deficit conditions in Iran. Appl. Ecol. Environ. Res. 2018, 16, 617-627. [CrossRef]

67. Jiang, P.; Cai, F.; Zhao, Z.-Q.; Meng, Y.; Gao, L.-Y.; Zhao, T.-H. Physiological and dry matter characteristics of spring maize in northeast china under drought stress. Water 2018, 10, 1561. [CrossRef]

68. Mansour, E.; Abdul-Hamid, M.I.; Yasin, M.T.; Qabil, N.; Attia, A. Identifying drought-tolerant genotypes of barley and their responses to various irrigation levels in a Mediterranean environment. Agric. Water Manag. 2017, 194, 58-67. [CrossRef]

69. Sohail, A.; Anwar, S.; Khan, M.O.; Nawaz, S.; Shah, F.A.; Ali, I.; Iqbal, J.; Ahmad, J.; Ahmad, F.; Nawaz, H. Response of planting methods and deficit irrigation on growth and yield attributes of maize under semi-arid conditions. Pure Appl. Biol. 2019, 8 , 706-717.

70. Nawaz, H.; Hussain, N.; Jamil, M.; Yasmeen, A.; Bukhari, A.; Auringzaib, M.; Usman, M. Seed biopriming mitigates terminal drought stress at reproductive stage of maize by enhancing gas exchange attributes and nutrient uptake. Turk. J. Agric. For. 2020, 44, 250-261. [CrossRef]

71. Attia, A.; El-Hendawy, S.; Al-Suhaibani, N.; Tahir, M.U.; Mubushar, M.; dos Santos Vianna, M.; Ullah, H.; Mansour, E.; Datta, A. Sensitivity of the DSSAT model in simulating maize yield and soil carbon dynamics in arid Mediterranean climate: Effect of soil, genotype and crop management. Field Crops Res. 2021, 260, 107981. [CrossRef]

72. Khan, A.; Shah, T.; Khan, S.; Rehman, A.; Akbar, H.; Muhammad, A.; Khalil, S. Influence of seed invigoration techniques on germination and seedling vigor of maize (Zea mays L.). Cercet. Agron. Mold. 2017, 50, 61-70. [CrossRef]

73. Bakht, J.; Shafik, M.; Jamal, Y.; Sher, H. Response of maize (Zea mays L.) to seed priming with NaCl and salinity stress. Span. J. Agric. Res. 2011, 252-261. [CrossRef]

74. Farajollahi, Z.; Eisvand, H.R. Storage duration and temperature of hydroprimed seeds affects some growth indices and yield of wheat. Plant Physiol. 2016, 7, 1909-1917.

75. Carter, D.; Harris, D.; Youngquist, J.; Persaud, N. Soil properties, crop water use and cereal yields in Botswana after additions of mulch and manure. Field Crop. Res. 1992, 30, 97-109. [CrossRef]

76. Damalas, C.A.; Koutroubas, S.D.; Fotiadis, S. Hydro-priming effects on seed germination and field performance of faba bean in spring sowing. Agriculture 2019, 9, 201. [CrossRef]

77. Gholami, M.; Mokhtarian, F.; Baninasab, B. Seed halopriming improves the germination performance of black seed (Nigella sativa) under salinity stress conditions. J. Crop Sci. Biotechnol. 2015, 18, 21-26. [CrossRef]

78. Eskandari, H.; Kazemi, K. Effect of seed priming on germination properties and seedling establishment of cowpea (Vigna sinensis). Not. Sci. Biol. 2011, 3, 113-116. [CrossRef]

79. Shrestha, A.; Pradhan, S.; Shrestha, J.; Subedi, M. Role of seed priming in improving seed germination and seedling growth of maize (Zea mays L.) under rain fed condition. J. Agric. Nat. Resour. 2019, 2, 265-273. [CrossRef] 
80. Gao, Y.-P.; Young, L.; Bonham-Smith, P.; Gusta, L.V. Characterization and expression of plasma and tonoplast membrane aquaporins in primed seed of Brassica napus during germination under stress conditions. Plant Mol. Biol. 1999, 40, 635-644. [CrossRef] [PubMed]

81. Jung, H.W.; Tschaplinski, T.J.; Wang, L.; Glazebrook, J.; Greenberg, J.T. Priming in systemic plant immunity. Science 2009, 324, 89-91. [CrossRef] [PubMed]

82. Gamir, J.; Sánchez-Bel, P.; Flors, V. Molecular and physiological stages of priming: How plants prepare for environmental challenges. Plant Cell Rep. 2014, 33, 1935-1949. [CrossRef]

83. Conrath, U.; Beckers, G.J.; Flors, V.; García-Agustín, P.; Jakab, G.; Mauch, F.; Newman, M.-A.; Pieterse, C.M.; Poinssot, B.; Pozo, M.J. Priming: Getting ready for battle. Mol. Plant Microbe Interact. 2006, 19, 1062-1071. [CrossRef]

84. Langeroodi, A.; Noora, R. Seed priming improves the germination and field performance of soybean under drought stress. J. Anim. Plant Sci. 2017, 27, 1611-1621.

85. Serraj, R.; Sinclair, T. Osmolyte accumulation: Can it really help increase crop yield under drought conditions? Plant Cell Environ. 2002, 25, 333-341. [CrossRef] [PubMed] 